\title{
Kematian akibat Kekerasan Tumpul Kepala pada Korban Anak yang Ditemukan di Dalam Sumur: Laporan Kasus
}

\author{
Dewanto Y. Priyambodo, IBG Surya P. Pidada
}

Departemen Ilmu Kedokteran Forensik dan Medikolegal Fakultas Kedokteran Universitas Gadjah Mada/Rumah Sakit Umum Pusat Dr. Sardjito Daerah Istimewa Yogyakarta, Indonesia Email: dewanto.y@ugm.ac.id; suryapidada@ugm.ac.id

\begin{abstract}
Violence against women and children still occurs in Indonesia. Some of them resulted in serious injuries and deaths. We reported a 13-year-old woman found dead in a well after missing for two days. The victim was buried immediately by the family after being found since there was no suspicion of homicide. Albeit, the police investigation developed into a homicide suspicion, therefore, an exhumation was carried out seven days after the death. There was no sign of violence on external inspection. Internal examination revealed bruising on the right cranium, reddened right brain tissue, and incomplete fracture at the base of the right cranium confirmed as intravital injury by microscopic examination. The pulmonary diatom examination showed negative result, therefore, the victim was pronounced dead before being put into the well. Spermatozoa's heads were found on the vaginal swab microscopic examination. In conclusion, the cause of death was a blunt trauma to the head by homicide. The victim died more than 24 hours from the time of examination.
\end{abstract}

Keywords: violence against woman; advantage of exhumation

\begin{abstract}
Abstrak: Kekerasan terhadap perempuan dan anak masih banyak terjadi di Indonesia. Beberapa di antaranya berakibat luka berat dan kematian. Seorang perempuan berusia 13 tahun ditemukan meninggal di dalam sumur setelah dinyatakan hilang selama 2 hari. Korban awalnya diduga meninggal karena bunuh diri. Korban dimakamkan segera oleh keluarga setelah ditemukan dan tidak ada kecurigaan pembunuhan. Penyidikan oleh polisi berkembang menjadi dugaan pembunuhan, sehingga dilakukan ekshumasi pada tujuh hari pasca kematian. Tidak terdapat tanda kekerasan pada pemeriksaan luar. Pemeriksaan dalam menunjukkan memar pada cranium sebelah kanan, jaringan otak sebelah kanan yang berwarna lebih merah dan retak pada basis cranii bagian kanan dan dikonfirmasi sebagai luka intravital melalui pemeriksaan mikroskopik. Pemeriksaan diatom paru menunjukkan hasil negatif sehingga korban dinyatakan meninggal sebelum dimasukkan ke dalam sumur. Pada pemeriksaan swab vagina didapatkan adanya kepala spermatozoa. Simpulan laporan kasus ini ialah sebab kematian korban oleh trauma tumpul pada kepala dengan cara dibunuh. Jenazah meninggal lebih dari 24 jam dari saat pemeriksaan.
\end{abstract}

Kata kunci: kekerasan terhadap perempuan; manfaat ekshumasi

\section{PENDAHULUAN}

Kekerasan terhadap perempuan dan anak masih menjadi masalah utama di seluruh dunia, terutama di Indonesia. ${ }^{1}$ Pada penelitian Pongoh et $\mathrm{al}^{1}$ di Manado, seluruh korban meninggal dengan riwayat kekerasan disertai kejahatan seksual terjadi pada korban perempuan dan umumnya merupakan kekerasan tumpul pada kepala dan leher. Kekerasan tersebut banyak terjadi di rumah dan dilakukan oleh keluarga dari anak dan perempuan tersebut. Kematian akibat cedera masih banyak terjadi pada usia produktif dan menempati proporsi terbesar setelah penyakit infeksi maupun noninfeksi. Kebanyakan cedera yang terjadi dan berakibat kematian merupakan kekerasan tumpul di daerah kepala. ${ }^{1,2}$ 
Kepala dan leher menjadi bagian tubuh yang paling banyak terdampak kekerasan, dan biasanya merupakan rangkaian dari kekerasan seksual. Kekerasan yang terjadi pada kepala seringkali fatal yang mengakibatkan cedara berat dan meninggalnya korban. Kematian akibat cedera menjadi penyebab kematian terbanyak setelah stroke dan hipertensi. Kekerasan yang terjadi pada perempuan seringkali disertai dengan persetubuhan, baik atas paksaan maupun suka sama suka. ${ }^{1-4}$

Pemahaman mengenai kekerasan sangat penting dalam dunia kedokteran forensik mengingat banyaknya kematian korban akibat kekerasan atau cedera tersebut. Berdasarkan latar belakang yang telah diuraikan maka penulis mengemukakan suatu laporan kasus kematian akibat kekerasan tumpul pada kepala terhadap korban seorang anak perempuan.

\section{LAPORAN KASUS}

Seorang anak perempuan usia 13 tahun dinyatakan hilang pada tanggal 21 April 2016. Dua hari kemudian, jenazah ditemukan di dalam sumur di dekat rumah korban. Karena diduga bunuh diri dengan menceburkan diri ke dalam sumur, orang tua korban memutuskan untuk mengubur jenazah korban setelah visum awal oleh petugas puskesmas setempat. Beberapa hari kemudian, polisi melakukan penyidikan berdasarkan laporan orang hilang dan menduga adanya tindak kriminal pembunuhan. Polisi meminta tim Kedokteran Forensik RSUP Dr. Sardjito untuk melakukan ekshumasi pada tanggal 30 April 2016.

Pada pemeriksaan saat ekshumasi didapatkan seluruh jenazah dalam kondisi membusuk. Pada pemeriksaan luar didapatkan bahwa luka-luka yang ada pada jenazah tidak dapat dinilai lagi. Tidak teraba derik tulang pada seluruh bagian tubuh.

Pemeriksaan dalam menunjukkan seluruh organ terlihat utuh, namun dalam keadaan membusuk. Didapatkan adanya memar pada kulit kepala bagian dalam dan fraktur pada calvaria cranii. Konfirmasi menggunakan pemeriksaan mikroskopik menunjukkan adanya tanda intravital. Pada dasar tulang kepala bagian depan tengah, terdapat retak tulang memanjang melalui tepi tengah melintasi tegmen tympani hingga mencapai fossa posterior (Gambar 1,2).

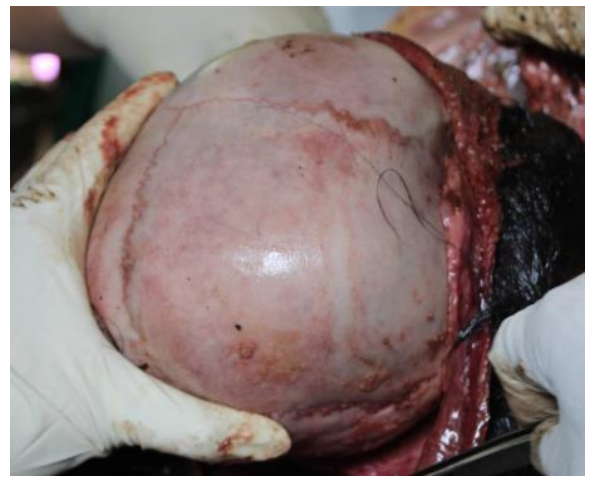

Gambar 1. Penampakan tengkorak bagian luar

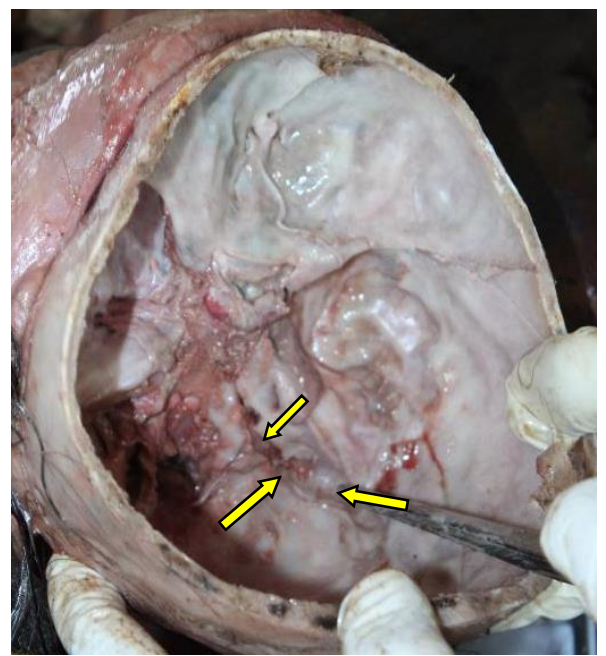

Gambar 2. Temuan retak pada tulang tengkorak bagian dalam

Pada permukaan dalam jalan nafas terdapat sisa jendalan darah, tidak ditemukan bintik perdarahan. Pada kedua paru setelah dilakukan pengirisan terdapat cairan warna merah berbuih. Pemeriksaan diatom menggunakan sampel jaringan paru tidak menunjukkan hasil positif, sementara pada air sumur terdapat diatom. Pemeriksaan toksikologi arsen dan sianida pada tanah di sekitar makam dan organ-organ dalam tubuh menunjukkan hasil negatif. Pada pemeriksaan vagina tidak terlihat adanya cairan dalam liang vagina (Gambar 3) namun pemeriksaan mikroskopik apusan vagina menunjukkan adanya kepala sperma. 


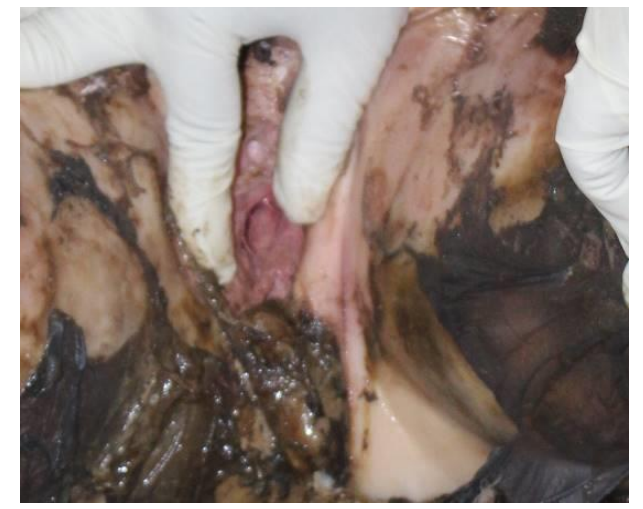

Gambar 3. Tidak terlihat adanya cairan pada liang vagina

\section{BAHASAN}

Hasil pemeriksaan kasus ini menyimpulkan bahwa sebab kematian ialah kekerasan tumpul pada kepala sebelah kanan.

Pemeriksaan diatom menggunakan sampel jaringan paru tidak menunjukkan hasil positif, sementara dalam air sumur terdapat diatom. Pemeriksaan diatom dilakukan untuk menentukan apakah korban meninggal setelah atau sebelum masuk ke dalam air. Jika ditemukan diatom dalam jumlah tertentu pada organ dalam (paru, ginjal, tulang, ataupun otak) maka dapat disimpulkan bahwa kemungkinan besar korban masih dalam keadaan hidup saat masuk ke dalam air, sehingga air beserta diatom masuk ke dalam tubuh jenazah. Pada korban yang meninggal sebelum dimasukkan ke dalam air, epiglotis menutup dan tidak ditemukan diatom pada organ dalam jenazah. ${ }^{5-7}$ Hasil pemeriksaan diatom pada kasus ini menunjukkan bahwa korban tidak meninggal dengan cara ditenggelamkan maupun berada di air pada saat masih hidup. Korban meninggal sebelum dimasukkan ke dalam sumur.
Persetubuhan dikonfirmasi dengan adanya sel sperma pada apusan vagina. Pemeriksaan mikroskopik apusan vagina menunjukkan adanya kepala sperma; hal ini selaras dengan pernyataan Cummings dan Trelka, ${ }^{8}$ yaitu dalam interval 3-5 hari pasca koitus, hanya ditemukan kepala sperma saja (Tabel 1). Jenazah telah meninggal lebih dari 24 jam dari saat pemeriksaan.

Interval saat kematian sulit ditentukan pada kasus ini karena telah terjadi pembusukan lanjut pada jenazah. Pada kasus ini, penggalian makam dilakukan pada hari ketiga pasca pemakaman. Penggalian kronologis kejadian mungkin dapat membantu menentukan saat kematian. ${ }^{9}$

Kondisi jenazah pada saat ekshumasi seringkali dalam keadaan membusuk dan akan menyulitkan pemeriksaan terhadap luka-luka pada jenazah. Hal ini juga terjadi pada kasus yang diperiksa. Adanya perlukaan fatal pada cranium mempermudah dokter dalam menentukan sebab kematian.

Luka pada jaringan lunak akan menghilang pada interval post mortem yang bervariasi. Luka pada kulit akan tersamarkan setelah 24 jam. Luka pada organ dalam menghilang pada interval yang bervariasi, bergantung vaskularisasi pada organ tersebut. Semakin banyak vaskularisasi, makin cepat organ tersebut membusuk sehingga cedera akan lebih sulit dinilai. Organ seperti prostat dan uterus relatif lebih lama membusuk. Organ otak kaya dengan vaskularisasi dan jaringan ikat yang tidak kuat sehingga cepat membusuk dengan bentuk membubur. ${ }^{10}$ Perlukaan yang mengenai hingga tulang relatif mudah ditemukan dan dilakukan pemeriksaan.

Tabel 1. Temuan sperma pada beberapa interval pasca koitus ${ }^{8}$

\begin{tabular}{|c|c|c|}
\hline $\begin{array}{c}\text { Periode } \\
\text { pasca koitus }\end{array}$ & $\begin{array}{l}\text { Penampakan } \\
\text { mikroskopik }\end{array}$ & Histokimiawi Enzimatik \\
\hline$<12$ jam & $\begin{array}{l}\text { Sperma motil lengkap } \\
\text { dengan ekor }\end{array}$ & $\begin{array}{l}\text { Asid fosfatase (+) } \\
\text { P30 (+) }\end{array}$ \\
\hline 12-24 jam & $\begin{array}{l}\text { Sperma non-motil, } \\
\text { lengkap dengan ekor }\end{array}$ & 18-24 jam : Asid fosfatase tidak terdeteksi \\
\hline 1-5 hari & Hanya kepala sperma & 24-48 jam: P30 tidak terdeteksi \\
\hline
\end{tabular}


Selain itu, luka pada tulang masih dapat ditemukan hingga jangka waktu pemakaman yang lama. Pemeriksaan penunjang berupa pemeriksaan histopatologik dapat dilakukan untuk melihat apakah perlukaan tersebut terjadi sebelum atau seudah kematian. Perlukaan pada tengkorak berupa fraktur berhubungan dengan perdarahan pada otak. Perdarahan sebanyak $35-100 \mathrm{~mL}$ dianggap fatal karena mengganggu status neurologik korban. ${ }^{10}$ Karena kondisi jenazah yang membusuk, perdarahan pada otak tidak dapat diukur.

Pemeriksaan dengan ekshumasi seperti yang dilakukan pada kasus ini merupakan salah satu jenis pemeriksaan dalam kedokteran forensik. Pengertian ekshumasi sendiri adalah penggalian jenazah yang telah dimakamkan (inhumasi) untuk pemeriksaan postmortem. Otopsi pertama maupun reotopsi dilakukan saat ekshumasi untuk menemukan informasi baru. Ekshumasi memiliki beberapa kelemahan sehingga harus dipertimbangkan matang-matang terkait beberapa hal, seperti biaya dan manfaat yang akan diperoleh. ${ }^{11}$

Setiap kasus kematian harus dilakukan otopsi sesegera mungkin setelah penemuan jenazah agar tanda-tanda patologik makroskopik dan mikroskopik lebih jelas ditemukan, misalnya adanya perdarahan. Koordinasi dan edukasi pada petugas medis dan polisi dapat mempercepat deteksi adanya kematian tidak wajar, sehingga pemeriksaan dapat segera dilakukan setelah jenazah ditemukan. ${ }^{11}$

\section{SIMPULAN}

Penyebab kematian pada kasus ini ialah kekerasan tumpul pada kepala yang menyebabkan cedera pada tulang tengkorak dan jaringan otak. Korban telah meninggal sebelum dimasukkan ke dalam sumur.

Ekshumasi dapat digunakan untuk mencari bukti-bukti pada jenazah, namun tidak sebaik otopsi pada jenazah yang baru saja meninggal dan belum dikuburkan. Kasus kriminalitas harus segera dilaporkan kepada penyidik dan ditindaklanjuti agar penanganan dapat berjalan dengan cepat. Bukti-bukti pada jenazah yang membusuk tidak sebaik yang ada pada jenazah yang belum membusuk.

\section{Konflik Kepentingan}

Penulis menyatakan tidak terdapat konflik kepentingan dalam studi ini.

\section{DAFTAR PUSTAKA}

1. Pongoh A, Mallo J, Siwu J. Pola kekerasan pada korban kejahatan seksual yang meninggal dan diperiksa di RSUD Prof. Dr. R. D. Kandou Manado. e-CliniC. 2013;1(2).

2. Djaja S. Transisi Epidemiologi di Indonesia dalam dua dekade terakhir dan impli-kasi pemeliharaan kesehatan menurut survei kesehatan rumah tangga, Surkesnas, Riskesdas (1986-2007). Buletin Penelitian Kesehatan. 2012;40(3):142-53.

3. Badan Penelitian dan Pengembangan Kesehatan. Riset Kesehatan Dasar (RISKESDAS) 2007. Lap Nas 2007. 2008; p. 1384. Available from: http://labdata. litbang.kemkes.go.id/images/download/la poran/RKD/2007/lap_rkd07.pdf

4. Kalangit A, Mallo J, Tomuka D. Peran Ilmu Kedokteran Forensik dalam pembuktian tindak pidana pemerkosaan sebagai kejahatan kekerasan seksual. e-CliniC. 2013.1 (1):1-11.

5. Verma K. Role of Diatoms in the World of Forensic Science. J Forensic Res. 2013; 4(2):181-4. Doi:10.4172/2157-7145.1000 181.

6. Pla-rabés S, Hamilton PB, Ballesteros E, Gavrilo M, Friedlander AM, Sala E. The structure and diversity of freshwater diatom assemblages from Franz Josef Land Archipelago : a northern outpost for freshwater diatoms. 2016;1-22. PeerJ. 2016;4:e1705. Doi: 10.7717/peerj.1705. eCollection 2016.

7. Payne-James JJ, Jones R, Karch SB, Manlove J. Simpson's Forensic Medicine (13th ed). London: Hodder Stought Ltd, 2011; p. 13, 264.

8. Cummings PM, Trelka DP, Springer KM. Atlas of Forensic Histopathology. Cambridge: Cambridge University Press; 2011.

9. Kojo N, Siwu J, Mallo JF. Efektifitas ekshumasi dalam memperkirakan saat mati di Bagian Ilmu Forensik dan Medikolegal FK UNSRAT BLU RSUP Prof. Dr. R. D. 
Kandou. e-CliniC. 2015;3:658-62.

10. Bardale R. Principles of Forensic Medicine and Toxicology. New Delhi: Jaypee Brothers Medical Publishers (P) LTD; 2011.

11. Saukko P, Knight B. Knight's Forensic
Pathology [Internet]. Bureau S, Vandenbergh L, Ueberberg A, Smith D, Larking S, editors. Hachette Livre, United Kingdom: Edward Arnold (Publishers) Ltd; 2004. Available from: www. hoddereducation.com 